Fall 2008

\title{
Counteracting linguicism: The Potential of ESL/bilingual education field experiences in teacher education
}

\author{
Tonda Liggett \\ Washington State University Vancouver
}

Follow this and additional works at: https://digitalscholarship.unlv.edu/jpme

\section{Repository Citation}

Liggett, Tonda (2008) "Counteracting linguicism: The Potential of ESL/bilingual education field experiences in teacher education," Journal of Praxis in Multicultural Education: Vol. 3: No. 1, Article 5. DOI: 10.9741/2161-2978.1013 Available at: https://digitalscholarship.unlv.edu/jpme/vol3/iss1/5

This Article is protected by copyright and/or related rights. It has been brought to you by Digital Scholarship@UNLV with permission from the rights-holder(s). You are free to use this Article in any way that is permitted by the copyright and related rights legislation that applies to your use. For other uses you need to obtain permission from the rights-holder(s) directly, unless additional rights are indicated by a Creative Commons license in the record and/ or on the work itself.

This Article has been accepted for inclusion in Journal of Praxis in Multicultural Education by an authorized administrator of Digital Scholarship@UNLV. For more information, please contact digitalscholarship@unlv.edu. 


\section{Counteracting Linguicism: The Potential of ESL/Bilingual Education Field Experiences in Teacher Education}

\section{Tonda Liggett}

There are many influential factors that contribute to an individual's self-identity, such as race, ethnicity, culture, class, gender, sexual orientation, religion, physical ability, age, and so on. In studies of American mainstream teachers and the factors that influence their pedagogy, White racial membership and the cultural positionality that this inherently implies, has been shown to have implications for teacher/student interactions in ways that limit minority student academic achievement (Delpit, 1995; Ladson-Billings, 2001; Sleeter, 1996). Research on the impact of field-based components within teacher education programs has highlighted the potential of raising awareness about diversity issues, yet little research exists that focuses particularly on English as a second language (ESL) or bilingual-based exchanges in demystifying preservice teachers' notions of immigrants and English language learners (e.g., Canagarajah, 1999; Cochran-Smith, 1995; Kubota, 2001; Mahboob, 2006; Motha, 2006a; Motha, 2006b; Pennycook, 1998).

This disconnect is further complicated by the embedded nature of racial and cultural assumptions, making it difficult for teachers to know the extent to which their own ideologies are influenced by the assumptions they make of people from different backgrounds (author, 2007; Hinkel, 1999). Addressing the relatively unexamined culture of the self is important in confronting underlying issues of power that work to sustain certain knowledge forms and solidify the positionality of the white race in the context of English language learning (Kubota, 2001) - with the result of the racial-cultural divide in school achievement. Being unaware of how dominant culture validates knowledge structures such as written and spoken discourse could cause teachers to misinterpret the alternative knowledge structures that inform their students thinking in ways that disadvantage, rather than empower them.

The underlying set of factors that directly generate the discursive field take place at what Foucault (1972) calls the preconceptual level. One social consequence of this discursive field is the establishment of a hierarchy of

Tonda Liggett is an Assistant Professor of ESL/Literacy at Washington State University Vancouver. Her research interests focus on the intersections of race, language, and culture. She teaches courses in bilingual/ESL education, social context, and linguistics. 
humankind where racial classification - the ordering of human groups on the basis of inherited or environmental differences-implies that certain races are superior to others (Goldberg, 1993). Breaking down preconceptions and dismantling the established discursive fields are necessary acts in preparing teachers for diverse classrooms.

Language and race are closely linked as a means of distinguishing Self and Other (Mahboob, 2006; Motha, 2006b; Pennycook, 1998). Underlying the intersection of language and race is a language ideology that Shuck (2001) calls "the ideology of nativeness," an Us-versus-Them division where native and nonnative speakers of a language are perceived as mutually exclusive, uncontested, and identifiable. Language becomes racialized as the native and nonnative English speaker hierarchy maps onto existing hierarchical structures in the collective conscious. The convergence of these models construct a social order that subconsciously frames language use in connection with racial membership.

Phillipson (1992) argues that "[L]inguicism has taken over from racism as a more subtle way of hierarchizing social groups in the contemporary world" (p. 241). This subtlety is realized not through separate forms of symbolic domination, but rather through ideological structures that provide discursive resources for laypersons, public figures, and academics alike to systematically connect linguistic discrimination and racism (Shuck, 2006). Discourse surrounding language use is bound by political and social constructs that frame its expressibility today, as seen in English Only initiatives throughout the United States, in the passing of English Only legislation in several states, and in the elimination of federal funding for bilingual public school programs. Such institutional actions reflect the macrosocial conditions that have enabled linguicism to emerge and pervade social and personal identity through common assumptions of truth that authorize linguistic exclusions. Disrupting misconceptions about language proficiency is important in teacher education as teacher educators strive to prepare preservice teachers to address the needs of racially and linguistically diverse student populations. Below I examine research on field-based components of teacher education to locate the potential for counteracting linguicism.

\section{Theoretical Framework}

Over the last decade, teacher preparation programs at colleges and universities across the United States have attempted to respond to the challenges of preparing teachers for the increasing diversity that is represented in public schools today. Teacher programs have responded to these challenges by altering courses, curriculum, fieldwork experiences, and other policies to include a 
diversity and multicultural education focus (Cochran-Smith \& Zeichner, 2005). Such a response has indicated that preservice teachers often enter teacher education courses with no conception of, interest in, or concern about cultural and racial diversity (Milner, 2005). They adopt color-blind (author, 2008; Johnson, 2002; Lewis, 2001; Milner, 2007) and culture-blind ideologies (Ford, Moore, \& Milner, 2005) that obscure the enormous, central, and profound influences that race and culture have on an individual's teaching and learning. Thus, courses that endeavor to provide preservice teachers with the knowledge base and understanding necessary to teach in highly diverse and urban classrooms must consider that many preservice teachers will enter these courses without any (or very limited) prior knowledge and understanding of diversity or of individuals quite different from themselves (Cochran-Smith, 1995; LadsonBillings, 2001).

One way to expand preservice teachers knowledge base about diversity is to provide experiences in teacher education programs in order to work directly with students from racial, cultural, and linguistic backgrounds that are different from their own. Teacher candidates benefit from engaging in community-based experiences with members of a diverse culture by increasing their selfawareness and understanding of ways to promote cultural pluralism in the classroom (Deering \& Stanutz, 1995; Mahan, 1982). Through these interactions, individual stereotypes are deconstructed and reconfigured. Gipe, Duffy, and Richards (1989) studied the impact of different types of early field experiences on candidates' attitudes, beliefs, and perceptions of teaching reading and language arts to urban, low-SES, dialect-speaking students. In terms of linguistic difference, they found that candidates had increased positive responses to dialect-speaking students. Similar research studies support the positive influence of field-based experiences on increased awareness of diversity issues for preservice teachers (Delpit, 1995; Ladson-Billings, 2001; Olmedo, 1997; Potthoff, et.al., 2000).

\section{The Study}

The analysis in this paper stems from a course titled, Bilingual and ESL Methods for $K$-8 Educators, one course in an intensive 15 month Master's in Teaching program at a university in the Pacific Northwest. Coordinated with a local elementary school, this course was an opportunity for preservice teachers to gain practical experience working with English language learners (ELLs). The purpose of the course was to assist teaching candidates to develop strategies that would enable ELLs to become more proficient readers and writers, and to heighten awareness of the impact of immigration and the influence of poverty, race, and culture on language learning. Opportunities to reflect on personal 
identity factors were built into course assignments, so that the influence could be related to teaching and pedagogy. Much of the reading material in the course addressed the social inequities of institutional structures and the role of education in maintaining the marginalization of underrepresented populations, particularly nonnative English speakers.

The 16 preservice teachers spent approximately 45 minutes each course working one-on-one with Hispanic children who had recently immigrated or were of first or second-generation heritage. Teacher candidates spent this time discussing reading, generating ideas for writing, or assisting with other vocabulary, fluency, and comprehension activities. The data was collected from final reflection journals, lesson plans, and course evaluations. The journals required students to respond to what they had learned from the course experience, how it had impacted their thinking about the role of bilingual/ESL education in society, and their views on issues of equity and diversity.

The data was analyzed using a grounded theory method of coding as a way to apply analytical techniques for handling data, considering alternative meanings for phenomena, and systematically relating concepts (Strauss \& Corbin, 1998). The procedures for this analysis consisted of rereading all journal entries, lesson plan components, and evaluation comments to identify student work that specifically related to the inquiry focus of this research. From the narrowing of relevant excerpts, categories began to emerge for open coding. The categories were interconnected based on comparing and contrasting phenomena to identify discrepancies, inconsistencies, similarities, and divergences (Lincoln \& Guba, 1985). The results are discussed in more detail below.

\section{Bilingual/ESL Field-based Experience}

For many of the teacher candidates, the bilingual/ESL field experience was the first time they had ever worked with a child learning English. Most of them did not speak Spanish, so that being in a bilingual environment challenged them to decipher meaning in similar ways as many ELLs. One student commented, "I didn't understand what the teacher or children were saying, so I had to just rely on nonverbal clues." This situation pressed them to notice strategies used by classroom teachers to convey meaning, such as physical gestures and paraphrasing when explaining directions. Indeed, many developed an appreciation and heightened awareness of the difficulty that bilingual students faced trying to negotiate meaning from daily classroom activities and academic exercises. Such awareness highlighted the intellectual ability needed to translate between native and nonnative languages, and worked to deconstruct the connection that is often made between cognitive ability and language proficiency where limited proficiency is often linked to limited intellect (Arias, 
1986; Author, 2005; Nolasco \& Acevedo, 1985; Riding, 1985; Valdes, 1996). Students commented on course evaluations that, "Working with students in a bilingual classroom and in a bilingual immersion school was the BEST learning experience for working with \& understanding ESL students. I highly recommend this be kept in the course curriculum." "It was very useful to get real experience at the elementary school." The exposure of working with individual children intently decoding reading passages in a second, or sometimes third language was not only important to deconstructing notions of linguicism and reconfiguring negative stereotypes about Hispanic immigrants and academic achievement but also to instilling a sense of compassion and understanding for some of the preservice teachers.

While being in the classroom provided a practical glimpse into the learning situation of bilingual and ESL children, it was not entirely seamless or unproblematic. Some of the teacher candidates expressed frustration at not knowing Spanish. For example, listening to students read in Spanish from books that were used to improve fluency caused many of the preservice teachers to question the usefulness of being in a bilingual classroom. "I have no idea what's going on!" "How are we supposed to help them when we don't know the language?" In addition, the strategies that we were reading about and discussing in our course texts were not always evident in the ESL classes in which the teacher candidates were participating. While this discrepancy was valuable for discussion, there was sometimes no reinforcement of the methods advocated, making the teaching techniques for ESL students appear less specialized and more aligned with general components of "good teaching" (e.g. using visual supports, paraphrasing instructions, connecting topics to background experience, previewing reading). Such generalizations are detrimental to deconstructing linguicism as they, 1) minimize the language learning process and the educational gaps that ELLs may have when they enter American schools, and 2) portray the language learning process as fast and fairly straight-forward when in fact learning academic English can take between 5-7 years (Diaz-Rico \& Weed, 2006; Peregoy \& Boyle, 2007).

Course evaluation comments reflect this discrepancy. "More time spent in classes exposed to ELL strategies would have been nice." "Discussions could be more geared towards course content and more focused." I agree that more focused discussion would have clarified some of the discrepancies that teacher candidates noticed and would have highlighted the classroom teacher's rationale for using particular strategies. In addition, these discussions could raise awareness of the localized factors for why schools and school districts adopt curricula - often with mandates for specific implementation. For example, more discussion on the Reading First literacy program that this school was instructed to adopt would explain the reason why some of the teachers that were inconsistent with our texts. Also, the lack of appropriate bilingual reading 
material in one class was due to the material not arriving on time, forcing the teacher to piece together readings from various mainstream texts, often with more difficult vocabulary and unfamiliar cultural references. This everyday adaptation was inconsistent with the themes that the grade level was covering and almost impossible for this teacher to stay on top of.

An aspect of the field experience that worked to help clarify the relationship between course readings and classroom practices was the "Teacher Speaker Series." Each week a bilingual or ESL teacher would come into our class to discuss topics covered in our readings and relate them to their own teaching experience. These discussions were helpful for teacher candidates to became more aware of ESL strategies such as, the use of group and pair work to promote verbal development and reinforce reading comprehension. Students' final lesson plans reflected this reinforcement through allocated time for pair sharing, literature circles, and shared reading. In this sense, the time spent in the classrooms was helpful in that they were able to see some of the strategies advocated in our reading and implemented by the classroom teachers. In addition, the speaker series was informative for both, the classroom teachers as a way to better understand the university's role within the school as well as the preservice candidates to better understand the intricacies of coordinating, organizing, and conducting learning in a diverse classroom. Our last speaker, the school principal, answered questions and discussed issues that teacher candidates had identified throughout the semester as especially difficult for new teachers, such as how to address violence in written work, appropriate language use, religious issues, and the immediate concerns of employment and interviewing strategies.

\section{Conclusions and Recommendations}

The field-based experience prompted the teacher candidates in this study to question the relevance of strategies advocated in our course texts for facilitating English language development, and at times, conflated the unique needs of ELLs with those of mainstream students. While such questioning is a valuable component of learning, without explicitly addressing these issues as on-going topics of conversation throughout the field experience, the likelihood of deconstructing preconceived notions of linguicism can be diminished. Including components such as continual, explicit discussion about course readings and classroom practice is important to contextualize and comprehend the issues that come into play when teaching to a diverse group of students. Also, analyzing teaching strategies to problematize the broader social context that influences curricular decisions for schools and school districts is key to understanding the political, historical, and social context of education. 
I believe there is much potential for on-site teacher education courses to deconstruct linguicism and expand preservice teachers' notions of language learning. With the increasing number of English language learners in public schools, access to curricula rests more and more on the knowledge that teachers bring into the teaching profession. Sanders (1998) and Sanders and Horn (1998) argue that teacher quality is the single most important influence on school success and students' achievement, surpassing socioeconomic status, class size, family background, school context, and all other factors that influence achievement. Given the potential for teacher impact on student academic success, the role of field-based bilingual/ESL experiences in teacher education holds much possibility for deconstructing linguicism and negative stereotypes about immigrants and multilingualism to better ensure that all students succeed.

\section{References}

Arias, B. (1986). The context of education for Hispanic students: An overview. American Journal of Education, 95(1), 26-57.

Author, 2005.

Author, 2007.

Author, 2008.

Canagarajah, A. (1999). Resisting linguistic imperialism in English teaching. Oxford, UK: Oxford University Press.

Cochran-Smith, M. (1995). Color blindness and basket making are not the answers: Confronting the dilemmas of race, culture, and language diversity in teacher education. American Educational Research Journal, 32, 493-522.

Cochran-Smith, M. \& Zeichner, K.M. (2005). Studying teacher education: The report of the AERA panel on research and teacher education. Mahwah, NJ: Lawrence Erlbaum Associates, Publishers.

Deering, T.E. \& Stanutz, A. (1995). Preservice field experience as a multicultural component of a teacher education program. Journal of Teacher Education, 46(5), 390-394.

Delpit, L. (1995). Other people's children: Cultural conflict in the classroom. New York, NY: The New Press.

Diaz-Rico, L.T. \& Weed, K.Z. (2006). The crosscultural, language, and academic development handbook: A complete $K-12$ reference guide, $3^{\text {rd }}$ edition. Boston, MA: Pearson Education, Inc.

Ford, D.Y., Moore, J.L., \& Milner, H.R. (2005). Beyond culture blindness: A model of culture with implications for gifted education. Roeper Review, 27(2), 97-103.

Foucault, M. (1972). The archaeology of knowledge. New York, NY: Pantheon.

Gipe, J.P., Duffy, C.A., \& Richards, J.C. (1989). A comparison of two types of early field experiences. Reading Improvement, 26(3), 254-265.

Goldberg, D. (1993). Racist culture: Philosophy and the politics of meaning. Oxford, UK: Blackwell. 
Hinkel, E. (Ed.). (1999). Culture in Second Language Teaching and Learning. New York, NY: Cambridge University Press.

Johnson, L. (2002). "My eyes have been opened": White teachers and racial awareness. Journal of Teacher Education, 53,(2), 153-167.

Kubota, R. (2001). Discursive construction of the images of U.S. classrooms. TESOL Quarterly, 35, 9-38.

Ladson-Billings, G. (2001). Crossing over to Canaan: The journey of new teachers in diverse classrooms. San Francisco, CA: Jossey-Bass.

Lewis, A.E. (2001). There is no "race" in the schoolyard: Color-blind ideology in an (almost) all White school. American Educational Research Journal, 38(4), 781811.

Lincoln, Y.S., \& Guba, E.G. (1985). Naturalistic Inquiry. Beverly Hills, CA: Sage.

Mahan, J.J. (1982). Community involvement components in culturally-oriented teacher preparation. Education, 103(2), 163-172.

Mahboob, A. (2006). Confessions of an Enraced TESOL Professional. In A. Curtis \& M. Romney (Eds.), Color, race, and English language teaching: Shades of meaning. (pp. 173-188). Mahwah, NJ: Lawrence Erlbaum Associates.

Milner, H.R. (2005). Stability and change in prospective teachers' beliefs and decisions about diversity and learning to teach. Teaching and Teacher Education, 21(7), 767-786.

Milner, H.R. (2007). Preservice teachers' learning about cultural and racial diversity: Implications for urban education. Urban Education, 41(4), 343-375.

Motha, S. (2006a). Decolonizing ESOL: Negotiating linguistic power in U.S. public school classrooms. Critical Inquiry in Language Studies. 3(2\&3), 75-100. Mahwah, NJ: Lawrence Erlbaum Associates.

Motha, S. (2006b). Out of the safety zone. In A. Curtis \& M. Romney (Eds.), Color, race, and English language teaching: Shades of meaning. (pp. 161-172). Mahwah, NJ: Lawrence Erlbaum Associates.

Nolasco, M., \& Acevedo, M.L. (1985). Los ninos de la frontera. Mexico City, MX: Centro de Ecodesarrollo, Ediciones Oceano, S.A.

Olmedo, I.M. (1997). Challenging old assumptions: Preparing teachers for inner city schools. Teaching and Teacher Education, 13(3), 245-258.

Pennycook, A. (1998). English and the Discourses of Colonialism. New York, NY: Routledge.

Peregoy, S. F. \& Boyle, O. F. Boyle. (2005). Reading, Writing, and Learning in ESL: A Resource Book for K-12 Teachers, 4th edition. Boston, MA: Pearson Education, Inc.

Phillipson, R. (1992). Linguistic imperialism. Oxford, UK: Oxford University Press.

Potthoff, D.E., Dinsmore, J., Eifler, K., Stirtz, G., Walsh, T., \& Ziebarth, J. (2000). Preparing for democracy and diversity: The impact of a community-based field experience on preservice teachers' knowledge, skills, and attitudes. Action in Teacher Education, 22(1), 79-92.

Riding, A. (1985). Distant neighbors: Portrait of the Mexicans, New York, NY: Knopf. Sanders, W. (1998). Value-added assessment. The School Administrator, 24-27.

Sanders, W. \& Horn, S. (1998). Research findings from the Tennessee Value-Added 
Assessment System (TVAAS) database: Implications for educational evaluation and research. Journal of Personnel Evaluation in Education, 12(3), 247-256.

Shuck, G. (2001). Imagining the native speaker: The poetics of complaint in university student discourse. Unpublished doctoral dissertation, University of Arizona.

Shuck, G. (2006). Racializing the nonnative English speaker. In Journal of Language, Identity, and Education. (Eds.) Ricento, T. \& Wiley, T.G. Mahwah, NJ: Lawrence Erlbaum Associates, Publishers.

Sleeter, C. (1996). Multicultural education as social activism. Albany, NY: SUNY Press.

Strauss, A. \& Corbin, J. (1998). Basics of qualitative research: Techniques and procedures for developing grounded theory, second edition. Thousand Oaks: SAGE Publications.

Valdes, Guadalupe. (1996). Con respeto: Bridging the distances between culturally diverse families and schools, an ethnographic portrait. New York, NY: Teachers College Press. 